\title{
ANALISIS KEPATUHAN LAPORAN KEUANGAN KOPERASI BERDASARKAN SAK ETAP
}

\author{
Nia Yuniarsih \\ Program Studi Akuntansi \\ Fakultas Ekonomi Universitas Katolik Darma Cendika \\ Jalan Dr. Ir. H. Soekarno 201, Surabaya
}

\begin{abstract}
The objective of this research is to describe the compliance annual report Koperasi Sekar Melati IBI Kota Surabaya with Standar Akuntansi Keuangan Entitas Tanpa Akuntabilitas Publik (SAK ETAP). Operational definition this research to measure compliance are components of Financial Statements, Recognition, Measurement, Balance Sheet Account's, Income Statement Account's, Statement of Equity Exchange Account's, Cash Flow Statement Account's. The research method using descriptive analysis. The sampling technique used documentation of the Annual Financial Statement of Koperasi Sekar Melati IBI Kota Surabaya ended year 2015. The results of this study indicate that the Financial Statements Koperasi Sekar Melati IBI Kota Surabaya still not comply with the SAK ETAP.
\end{abstract}

\begin{abstract}
ABSTRAK
Tujuan dari penelitian ini adalah untuk menjelaskan kepatuhan Laporan Keuangan Koperasi Sekar Melati IBI Kota Surabaya dengan Standar Akuntansi Keuangan Entitas Tanpa Akuntabilitas Publik (SAK ETAP). Satuan Kajian yang digunakan dalam penelitian ini untuk mengukur kepatuhan antara lain Komponen Laporan Keuangan, Pengakuan, Pengukuran, Pos-pos Neraca, Pos-pos Perhitungan Hasil Usaha, Pos-pos Laporan Perubahan Ekuitas, dan Pos-pos Laporan Arus Kas. Metode penelitian menggunakan analisa deskriptif. Teknik pengambilan sampel menggunakan dokumentasi berupa Laporan Keuangan Koperasi Sekar Melati IBI Kota Surabaya Tahun 2015. Hasil dari penelitian ini menunjukkan bahwa Laporan Keuangan Koperasi Sekar Melati IBI Kota Surabaya masih belum mematuhi Standar Akuntansi Keuangan Entitas Tanpa Akuntabilitas Publik.
\end{abstract}

Keywords: financial statement, SAK ETAP 


\section{PENDAHULUAN}

Koperasi merupakan perkumpulan dari sejumlah orang yang bergabung secara sukarela untuk mencapai tujuan yang sama yang diawasi secara demokratis melalui penyetoran kontribusi yang sama untuk modal dan pembagian resiko serta manfaat yang wajar di mana para anggotanya berperan secara aktif (Partomo, 2009). Koperasi memiliki karakteristik utama yang membedakannya dengan entitas lain, yaitu: adanya sejumlah individu yang memiliki satu kepentingan yang sama, adanya harapan dari anggota untuk memperbaiki kondisi ekonominya dengan saling bantu membantu, adanya pembentukan suatu badan usaha.

Koperasi memiliki keunggulan karena dapat mewujudkan skala ekonomi, perlu dibuktikan bahwa skala ekonomi tersebut tidak hanya waktu khusus saja, melainkan koperasi mampu mewujudkan keunggulan tersebut. Koperasi diberi hak istimewa yang memungkinkan menahan masuknya pesaing bisnis yang lain (Sunarto, 2006).

Dalam era menghadapi Masyarakat Ekonomi ASEAN (MEA), laporan keuangan yang disusun oleh koperasi merupakan sarana terpenting dalam pengambilan keputusan ekonomi. Semakin berkembangnya kegiatan usaha koperasi, menuntut pengelolaan koperasi secara profesional dan memerlukan pertanggungjawaban yang baik serta menyajikan informasi yang relevan dan reliabel, untuk pengambilan keputusan ekonomi koperasi. Salah satu upaya tersebut adalah merumuskan standar akuntansi keuangan untuk koperasi sebagai pedoman penyusunan laporan keuangan- nya. Standar Akuntansi Keuangan Entitas Tanpa Akuntanbilitas Publik (SAK ETAP) telah disahkan pada tahun 2009 namun baru diterapkan dalam proses penyusunan Laporan Keuangan dimulai pada tanggal 1 Januari 2011. Selain itu, untuk mendukung agar informasi keuangan koperasi bermanfaat bagi pengguna, maka Pemerintah mengeluarkan Peraturan Menteri Koperasi dan Usaha Kecil dan Menengah Republik Indonesia Nomor 12/Per/M.KUKM/IX/2015 tentang Pedoman Umum Akuntansi Koperasi Sektor Riil yang merupakan penyempurnaan dari Peraturan Menteri Koperasi dan Usaha Kecil dan Menengah Republik Indonesia Nomor 04/Per/M. KUKM/VII/2012 serta Peraturan Menteri Koperasi dan Usaha Kecil dan Menengah Republik Indonesia Nomor 13/Per/M.KUKM/IX/2015 tentang Pedoman Umum Akuntansi Koperasi Simpan Pinjam.

Laporan Keuangan Koperasi merupakan penyajian yang terstruktur yang dimulai dari Penyajian hasil Usaha, Laporan Perubahan Ekuitas, Neraca, Laporan Arus Kas dan Catatan Atas Laporan Keuangan. Koperasi harus menyusun laporan keuangan sesuai dengan SAK ETAP dengan menggunakan dasar akrual, kecuali dalam penyusunan Laporan Arus Kas. Pos pos yang digunakan dalam dasar akrual antara lain aset, kewajiban, ekuitas, penghasilan (pendapatan) dan beban yang diakui sesuai dengan prinsip pengakuan. Adanya SAK ETAP diharapkan dapat memberikan kemudahan untuk koperasi dalam menyajikan laporan keuangan dan menjadi solusi permasalahan internal terutama bagi pengurus dan anggota 
yang ingin melihat berapa Sisa Hasil Usaha yang akan didapat (Hertiyo dan Hisamuddin, 2015). Dalam beberapa hal SAK ETAP memberikan banyak kemudahan untuk suatu entitas dibandingkan dengan SAK umum dengan ketentuan pelaporan yang lebih kompleks.

Salah satu koperasi yang berusaha menyusun Laporan Keuangan sesuai dengan standar akuntansi yang berlaku adalah Koperasi Sekar Melati - Ikatan Bidan Indonesia (IBI) Kota Surabaya. Koperasi tersebut sudah mendapatkan pengesahan sebagai badan hukum berdasarkan Surat Keputusan Nomor 8539/BH/II/1996 di mana anggotanya terdiri dari seluruh bidan dalam lingkup IBI Kota Surabaya beserta karyawan Rumah Sakit. Koperasi Sekar Melati IBI Kota Surabaya didirikan pada tanggal 26 September 1996. Keberadaan Koperasi Sekar Melati IBI Kota Surabaya dimaksudkan untuk meningkatkan kesejahteraan dalam lingkup anggota IBI dengan harapan volume pendapatan dan sisa hasil usaha untuk tahun berikutnya meningkat. Permasalahan yang sering muncul pada Koperasi Sekar Melati IBI Kota Surabaya adalah keterbatasan dana. Pihak perbankan dan mitra koperasi memiliki syarat yang berkaitan dengan pendanaan dan penyajian laporan keuangan yang relevan serta reliabel. Oleh karena itu, peneliti ingin melakukan analisis mengenai kepatuhan Koperasi Sekar Melati IBI Kota Surabaya dalam menyusun laporan keuangan berdasarkan SAK ETAP. Laporan keuangan yang disusun berdasarkan SAK ETAP akan memudahkan pihak bank atau investor dalam membaca laporan keuangan Koperasi Sekar Melati IBI Kota Surabaya dan dapat mengambil keputusan yang terbaik dalam hal investasi.

\section{TINJAUAN PUSTAKA \\ Pengertian Koperasi}

Koperasi merupakan badan usaha yang beranggotakan orangorang atau badan hukum. Koperasi merupakan organisasi ekonomi yang dikelola oleh para anggotanya, dengan dasar satu orang satu suara, dengan Sisa Hasil Usaha yang didistribusikan diantara para anggotanya sesuai dengan aturan yang telah disetujui (Sunarto, 2006). Prinsip koperasi berdasarkan asas kekeluargaan. Tujuan koperasi adalah memajukan kesejahteraan anggota dan masyarakat dalam rangka mewujudkan masyarakat yang adil dan makmur. Landasan koperasi berdasarkan Pancasila dan UndangUndang Dasar 1945. Fungsi koperasi berdasarkan Undang-Undang Republik Indonesia Nomor 25 tahun 1992 antara lain:

a. Mengembangkan potensi dan kemampuan ekonomi anggota untuk meningkatkan kesejahteraan ekonomi dan sosialnya.

b. Berperan secara aktif dalam upaya untuk meningkatkan kualitas kehidupan manusia.

c. Memperkokoh perekonomian rakyat sebagai dasar kekuatan dan ketahanan perekonomian nasional dengan koperasi sebagai sokogurunya.

d. Berusaha mengembangkan perekonomian nasional yang merupakan usaha bersama berdasar asas kekeluargaan dan demokrasi ekonomi.

Prinsip-prinsip utama pengelolaan koperasi antara lain:

a. Keanggotaan bersifat terbuka dan sukarela. 
b. Pengelolaan dilaksanakan secara demokratis.

c. Pembagian hasil usaha dilakukan secara adil sebanding dengan besarnya jasa usaha masing-masing anggota.

d. Pemberian balas jasa yang terbatas terhadap modal.

e. Kemandirian.

Menurut Anggawirya (2014) struktur permodalan koperasi terdiri dari:

a. Simpanan anggota yang dibagi menjadi 3 yaitu simpanan pokok, simpanan wajib dan simpanan sukarela.

b. Modal sumbangan.

c. Modal penyertaan.

d. Cadangan.

e. Sisa Hasil Usaha yang belum dibagi.

\section{Pengertian SAK ETAP}

Standar Akuntansi Keuangan

Entitas Tanpa Akuntabilitas Publik (SAK ETAP) digunakan oleh entitas tanpa akuntabilitas publik. Entitas tersebut memiliki karakteristik:

a. Tidak memiliki akuntabilitas publik secara signifikan.

b. Menerbitkan Laporan keuangan dengan tujuan umum bagi pengguna eksternal misalkan pihak kreditur.

\section{Pengertian Laporan Keuangan}

Laporan Keuangan merupakan sarana pengkomunikasian informasi keuangan kepada pihak pihak yang berkepentingan. Laporan keuangan disajikan dalam Neraca, Laporan Laba Rugi, Laporan Perubahan Modal, Laporan Arus Kas dan Catatan Atas Laporan Keuangan. Catatan Laporan Keuangan merupakan bagian integral yang tak terpisahkan dari setiap Laporan Keuangan. Menurut Kieso et al. (2007) tujuan disusun Laporan Keuangan antara lain :

a. Untuk pengambilan keputusan investasi, kredit dan keputusan serupa secara rasional.

b. Untuk membantu investor dalam menilai jumlah, penetapan waktu, dan ketidakpastian penerimaan kas masa depan.

c. Untuk memberikan gambaran mengenai sumber ekonomi dari suatu entitas dan klaim terhadap sumberdaya tersebut.

Menurut Ikatan Akuntan Indonesia (2009) komponen Laporan Keuangan terdiri dari:

a. Neraca atau yang disebut dengan Laporan Posisi Keuangan, menyajikan aktiva, kewajiban, dan ekuitas atau modal entitas pada suatu tanggal tertentu. Neraca menyajikan informasi mengenai sifat dan jumlah investasi dalam sumber daya entitas, kewajiban kepada kreditor, dan ekuitas pemilik dalam sumber daya bersih entitas. Manfaat neraca antara lain: menganalisis tingkat likuiditas, tingkat solvensi, dan tingkat profitabilitas suatu entitas. Informasi yang disajikan dalam Neraca antara lain: Kas dan Setara Kas, Piutang Usaha, Persediaan, Properti Investasi, Aset Tetap, Aset Tidak Berwujud, Utang Usaha, Kewajiban Jangka Panjang, Ekuitas.

b. Laporan Laba Rugi adalah laporan yang mengukur keberhasilan operasi perusahaan selama periode tertentu. Manfaat dari Laporan Laba Rugi yaitu untuk mengevaluasi kinerja masa lalu perusahaan, untuk memprediksi kinerja masa depan perusahaan, untuk menilai ketidakpastian atau resiko arus kas masa depan. Unsur-unsur Laporan Laba 
Rugi terdiri dari: pendapatan, beban keuangan, bagian laba rugi investasi yang menggunakan metode ekuitas, beban pajak, laba rugi neto.

c. Laporan Perubahan Ekuitas yaitu laporan yang menyajikan laba atau rugi entitas selama satu periode, pos pendapatan dan beban yang diakui secara langsung dalam ekuitas untuk periode tersebut, pengaruh prubahan kebijakan akuntansi dan koreksi kesalahan yang diakui dalam periode tersebut, jumlah investasi, deviden dan distribusi ke dan oleh pemilik ekuitas selama periode tersebut.

d. Laporan Arus Kas, merupakan laporan yang menyediakan informasi yang relevan mengenai penerimaan dan pembayaran kas sebuah entitas selama suatu periode. Isi dari Laporan Arus Kas terdiri dari Aktivitas Operasi, Aktivitas Investasi, dan Aktivitas Pembiayaan. Aktivitas operasi meliputi transasksi kas yang mempengaruhi penentuan laba bersih. Aktivitas Investasi meliputi transaksi yang berkaitan dengan pemberian dan penagihan pinjaman serta perolehan dan pelepasan investasi serta aktiva tetap. Aktivitas Pembiayaan melibatkan transaksi yang berhubungan dengan pos kewajiban dan ekuitas atau modal, antara lain perolehan sumber daya dari pemilik dan peminjaman uang dari kreditor serta pelunasannya.

e. Catatan Atas Laporan Keuangan, menyajikan informasi tentang dasar penyusunan Laporan Keuangan dan kebijakan akuntansi yang digunakan oleh entitas tersebut serta memberikan informasi tambahan yang tidak disajikan dalam Lapor- an Keuangan tetapi masih relevan untuk memahami isi dari Laporan Keuangan tersebut.

Menurut Ikatan Akuntan Indonesia dalam Sitepu (2015) pengguna Laporan Keuangan Koperasi antara lain :

a. Investor.

Investor membutuhkan informasi untuk membantu dalam menentukan apakah harus membeli, menahan, atau menjual investasi.

b. Karyawan.

Karyawan dan kelompok-kelompok yang mewakili tertarik pada informasi mengenai profitabilitas dan kondisi entitas yang stabil. Karyawan juga tertarik kepada entitas yang mampu memberikan informasi mengenai jaminan hari tua dan manfaat kerja.

c. Pemberi Pinjaman (Kreditur). Pemberi pinjaman tertarik dengan informasi yang menyajikan bahwa entitas mampu membayar kewajiban berupa pokok dan bunga dengan tepat waktu.

d. Pemasok dan kreditor lainnya. Pemasok tertarik dengan informasi yang menyajikan bahwa entitas mampu membayar hutang usahanya sesuai jatuh tempo.

e. Pelanggan.

Pelanggan tertarik dengan informasi yang menyajikan bahwa entitas mampu memberikan jaminan atas kelangsungan hidup entitas.

f. Pemerintah.

Pemerintah dan berbagai lembaga yang bekepentingan membutuhkan informasi mengenai aktivitas entitas, menetapkan standar penentuan pajak sebagai dasar untuk menentukan pendapatan nasional.

g. Masyarakat.

Penyajian laporan keuangan membantu masyarakat untuk memberi- 
kan informasi mengenai kecenderungan kemakmuran perusahaan beberapa tahun terakhir.

\section{Karakteristik Kualitatif Laporan Keuangan Koperasi}

Laporan keuangan menyediakan informasi yang relevan dan handal bagi tujuan pengambilan keputusan. Sementara itu pihak-pihak berkepentingan memahami isi dari laporan keuangan tersebut. Informasi yang disajikan sangat relevan dan handal, namun informasi tersebut tidak berguna bagi pemakai yang tidak memahaminya. Menurut Peraturan Menteri Koperasi dan Usaha Kecil dan Menengah Republik Indonesia Nomor 13/Per/M.KUKM/IX/2015 tentang Pedoman Umum Akuntansi Koperasi Simpan Pinjam karakteristik kualitatif Laporan Keuangan terdiri dari:

a. Dapat dipahami artinya informasi yang terkandung dalam laporan keuangan mudah dipahami oleh pengguna laporan keuangan.

b. Relevan artinya informasi keuangan harus relevan dengan kebutuhan pengguna untuk proses pengambilan keputusan dan membantu mengevaluasi kinerja entitas di masa lalu, masa kini dan masa depan.

c. Materialitas artinya informasi dianggap material jika terdapat kelalaian dalam mencantumkan atau kesalahan dalam mencatat yang mempengaruhi keputusan ekonomi.

d. Keandalan artinya ketika informasi tersebut bebas dari kesalahan material dan bias.

e. Substansi mengungguli bentuk artinya transaksi dicatat sesuai dengan substansi dan realitas ekonominya. f. Pertimbangan sehat artinya mengandung unsur kehati-hatian pada saat melakukan pertimbangan dalam kondisi ketidakpastian.

g. Kelengkapan artinya informasi yang terkandung harus lengkap dalam batasan materialitas dan biaya.

h. Dapat dibandingkan artinya pengguna laporan keuangan mampu membandingkan laporan keuangan antara periode sebelumnya dengan periode saat ini.

i. Ketepatan waktu artinya laporan keuangan disajikan sesuai dengan waktu yang telah ditentukan, sehingga dapat mempengaruhi keputusan ekonomi para pengguna laporan keuangan.

j. Biaya dan manfaat artinya informasi yang disajikan memberikan manfaat yang dapat dinikmati oleh pengguna laporan keuangan.

\section{Pengakuan, Pengukuran, Penyajian dan Pengungkapan}

Pengakuan merupakan proses pembentukan suatu pos dalam laporan keuangan yang mempunyai nilai atau biaya yang dapat diukur dan manfaat ekonomi yang berkaitan dengan pos tersebut mengalir dari dan ke dalam entitas. Pengakuan entitas dalam menyusun laporan keuangan menggunakan dasar akrual, kecuali menyusun Laporan Arus Kas. Berdasarkan dasar akrual pos-pos diakui sebagai aset, kewajiban, ekuitas, pendapatan dan beban ketika telah memenuhi kriteria untuk pos pos tersebut.

Pengukuran merupakan penetapan sejumlah nominal yag digunakan entitas untuk mengukur aset, kewajiban, pendapatan dan beban dalam laporan keuangan. Dasar pengukuran dalam penyusunan Laporan Keuangan Koperasi sesuai SAK ETAP ada dua, yaitu: 
a. Biaya historis yaitu jumlah kas atau setara kas yang dibayarkan atau nilai wajar dari pembayaran yang diberikan untuk memperoleh aset. Pada saat pengakuan awal transaksi, aset harus diakui sebesar biaya perolehannya.

b. Nilai wajar yaitu jumlah yang dipakai untuk menukarkan suatu aset atau menyelesaikan suatu kewajiban dalam suatu transaksi nilai wajar.

Penyajian merupakan proses penempatan pos dalam Laporan Keuangan dengan tepat dan wajar. Penyajian dan klasifikasi pos dalam laporan keuangan harus konsisten. Adanya perubahan diperbolehkan, jika standar mengharuskan adanya perubahan dalam penyajian dan terjadi perubahan yang signifikan dalam sifat operasi entitas tersebut.

Pengungkapan merupakan proses pemberian informasi tambahan yang dibutuhkan utnuk menjelaskan setiap pos kepada para pengguna laporan keuangan sebagai catatan dalam laporan keuangan koperasi.

\section{METODE PENELITAN}

\section{Jenis Penelitian dan Gambaran} Populasi (Objek) Penelitian

Jenis penelitian ini merupakan penelitian kualitatif dengan menggunakan metode analisis deskriptif dan tidak ada populasi maupun sampel karena menggunakan studi kasus pada Koperasi Sekar Melati IBI Kota Surabaya beralamat di Jalan Dupak Nomor 15A.

\section{Teknik Pengumpulan Data}

Teknik pengumpulan data yang dilakukan dalam penelitian ini adalah menggunakan metode dokumentasi.

\section{Satuan Kajian}

Satuan kajian dalam penelitian ini yaitu Laporan Keuangan Koperasi Sekar Melati IBI Kota Surabaya untuk tahun 2015. Berdasarkan penelitian Wahyuningsih (2014) kriteria dalam kepatuhan antara lain:

a. Komponen Laporan Keuangan.

b. Pengakuan.

c. Pengukuran.

d. Pos-pos Neraca.

e. Pos-pos Perhitungan Hasil Usaha.

f. Pos-pos Laporan Perubahan Ekuitas.

g. Pos-pos Laporan Arus Kas.

\section{Teknik Analisis Data}

Teknik analisis data yang digunakan dalam penelitian ini antara lain:

a. Menganalisis kelengkapan komponen Laporan Keuangan, terdiri dari Neraca, Perhitungan Hasil Usaha, Laporan Perubahan Ekuitas, Laporan Arus Kas dan Catatan atas Laporan Keuangan.

b. Menganalisis pengakuan dengan menggunakan dasar akrual.

c. Menganalisis pengukuran dengan menggunakan prinsip biaya historis.

d. Mengidentifikasi pos-pos yang terdapat dalam Neraca.

e. Mengidentifiksai pos-pos yang terdapat dalam Perhitungan Hasil Usaha.

f. Mengidentifikasi pos-pos yang terdapat dalam Laporan Perubahan Ekuitas.

g. Mengidentifikasi pos-pos yang terdapat dalam Laporan Arus Kas yang terdiri dari kegiatan operasi, kegiatan investasi dan kegiatan pendanaan. 


\section{PEMBAHASAN}

Ikatan Akuntan Indonesia (2009) menyatakan bahwa penyajian Laporan Keuangan harus mematuhi persyaratan SAK ETAP dan pengertian laporan keuangan yang lengkap. Disebutkan bahwa entitas yang laporannya mematuhi SAK ETAP harus membuat pernyataan eksplisit dan secara penuh atas kepatuhan tersebut dalam Catatan Atas Laporan Keuangan. Laporan Keuangan tidak boleh menyatakan mematuhi SAK ETAP, kecuali jika mematuhi semua persyaratan yang ada dalam SAK ETAP.

Komponen Laporan Keuangan yang disajikan dalam Rapat Anggota Tahunan Koperasi Sekar Melati IBI Kota Surabaya hanya Neraca dan Perhitungan Hasil Usaha. Sedangkan dalam SAK ETAP kepatuhan dalam menyajikan semua komponen Laporan Keuangan merupakan kewajiban. Adapun dampak Laporan Perubahan Ekuitas tidak dilaporkan yaitu, anggota tidak dapat melihat peningkatan atau penurunan kekayaan atau sisa hasil usaha dari tahun yang bersangkutan. Selain itu tidak disajikannya Laporan Arus Kas, menyebabkan anggota tidak mengetahui fluktuasi arus kas masuk dan arus kas keluar selama tahun bersangkutan. Pengurus tidak dapat mengevaluasi aktiva bersih Koperasi Sekar Melati IBI Kota Surabaya, dan tidak mampu menilai kas sekarang dengan kas masa depan. Koperasi Sekar Melati IBI Kota Surabaya tidak menyajikan Catatan Atas Laporan Keuangan, sehingga tidak terdapat infomasi yang relevan disetiap pos-pos dalam komponen Laporan Keuangan.

Pengakuan pos-pos yang terdapat dalam Neraca dan Perhitungan Hasil Usaha Koperasi Sekar Melati IBI
Kota Surabaya telah menggunakan dasar akrual. Hal ini dibuktikan dengan adanya pembebanan Piutang Tak Tertagih sebesar $1 \%$ dari total Piutang Usaha tahun 2015. Jurnal yang telah dibuat mendebet Beban Piutang Tak Tertagih dan mengkredit Penyisihan Piutang Tak tertagih. Hal ini sesuai dengan Peraturan Menteri Koperasi dan Usaha Kecil dan Menengah Republik Indonesia Nomor 13/Per/M.KUKM/ IX/2015 mengenai Pedoman Umum Akuntansi Koperasi Simpan Pinjam yang mewajibkan menyajikan estimasi piutang tak tertagih di setiap periode. Pengukuran dalam perolehan aktiva sesuai SAK ETAP menggunakan prinsip biaya historis, namun Koperasi Sekar Melati tidak memiliki aktiva tetap karena aktivitas operasional koperasi di Rumah Sakit IBI Kota Surabaya. Pengurus maupun anggota Koperasi Sekar Melati merupakan bidan dan karyawan Rumah Sakit IBI Kota Surabaya.

Pos-pos di dalam Neraca Koperasi Sekar Melati IBI Kota Surabaya telah mematuhi SAK ETAP yaitu dari Sisi Aktiva terdiri dari Kas, Piutang, Penyisihan Piutang Tak Tertagih. Dari Sisi Kewajiban terdiri dari Kewajiban Sukarela, Dana Pengurus, Dana Karyawan, Dana Pendidikan, dan Dana Sosial, serta dari sisi Ekuitas terdiri dari Simpanan Pokok, Simpanan Wajib, Cadangan, Donasi, Sisa Hasil Usaha. Namun, dalam komponen pos ekuitas terdapat pos Pendapatan Lain lain yang seharusnya pos tersebut terdapat dalam Perhitungan Hasil Usaha dengan posisi di bawah beban operasional koperasi. Alasannya, semua pendapatan dan beban yang menunjukkan kinerja Koperasi Sekar Melati IBI Kota Surabaya selama tahun berjalan dilaporkan 
dalam Perhitungan Hasil Usaha bukan dilaporkan dalam Neraca tahun bersangkutan.

Pos-pos yang terdapat dalam Perhitungan Hasil Usaha telah mematuhi SAK ETAP yaitu Pendapatan terdiri atas Pendapatan Bunga karena merupakan koperasi simpan pinjam dan Beban Usaha yang terdiri atas Honor Karyawan, Beban Penyisihan Piutang Tak Tertagih, Beban Lain-lain dan Beban Organisasi. Sebaiknya pos Pajak Penghasilan (badan) tidak dijadikan satu dengan Beban Organisasi, karena akan membingungkan dalam perhitungan pajak badan atas koperasi tersebut. Selain itu, jika kegiatan operasional Koperasi dilakukan di Rumah Sakit IBI Kota Surabaya sebaiknya terdapat pos Beban Sewa Bangunan dalam Biaya Operasionalnya, karena Rumah Sakit IBI Surabaya dan Koperasi Sekar Melati merupakan dua entitas yang berbeda sesuai dengan karakteristik substansi mengungguli bentuk. Penjelasan mengenai kelengkapan komponen, pengukuran, pengakuan, dan identifikasi setiap pos dalam Laporan Keuangan yang disajikan dalam Rapat Anggota Tahunan Koperasi Sekar Melati IBI Kota Surabaya di atas dapat ditarik kesimpulan bahwa dalam penyajian Laporan Keuangan masih belum mematuhi SAK ETAP. Laporan Perubahan Ekuitas, Laporan Arus Kas dan Catatan Atas Laporan Keuangan tidak disusun oleh pengurus Koperasi Sekar melati IBI Kota Surabaya.

\section{KESIMPULAN}

1. Laporan Keuangan Koperasi Sekar Melati IBI Kota Surabaya masih belum memenuhi kriteria kepatuhan sesuai SAK ETAP.
2. Laporan Keuangan Koperasi Sekar Melati IBI Kota Surabaya tidak menyajikan Laporan Perubahan Ekuitas, Laporan Arus Kas dan Catatan Atas Laporan Keuangan dalam Rapat Anggota Tahunan periode 2016.

3. Laporan Keuangan Koperasi Sekar Melati IBI Kota Surabaya telah disusun dengan dasar akrual. Tidak adanya penilaian atas aktiva tetap karena kegiatan administrasi koperasi dilakukan di Rumah Sakit IBI Kota Surabaya.

\section{SARAN}

1. Untuk periode selanjutnya diharapkan Koperasi Sekar Melati IBI Kota Surabaya dapat menyajikan Laporan Keuangannya secara lengkap sesuai dengan SAK ETAP dengan menyusun Laporan Perubahan Ekuitas, Laporan Arus Kas dan Catatan Atas Laporan Keuangan di samping Neraca dan Laporan hasil Usaha.

2. Perlu adanya pos Biaya Sewa, karena Rumah Sakit IBI dan Koperasi Sekar Melati IBI Surabaya merupakan dua entitas yang berdiri sendiri.

3. Perlu adanya penjabaran yang lebih terperinci mengenai setiap pos-pos biaya.

\section{DAFTAR KEPUSTAKAAN}

Anggawirya, Erhans, 2014, Akuntansi Berdasarkan Prinsip Akuntansi Indonesia: Jasa, Dagang Koperasi, Ercontra Rajawali, Jakarta.

Hertiyo, Dimas Andika dan Nur Hisamuddin, 2015, Laporan Keuangan Koperasi Serba Usaha Buah Katakasi Berbasis SAK 
ETAP, Artikel Ilmiah Mahasiswa, hal 1-7.

Ikatan Akuntan Indonesia, 2009, Standar Akuntansi Keuangan Entitas Tanpa Akuntabilitas Publik, Salemba Empat, Jakarta.

Kieso, Donald E, Jerry J. Weygandt, and Terry D. Warfield, 2007, $12^{\text {th }}$ edition, Intermediate Accounting, John Willey and Sons, New York.

Partomo, Tiktik Sartika, 2009, Ekonomi Koperasi, Ghalia Indonesia, Jakarta.

Peraturan Menteri Koperasi dan Usaha Kecil dan Menengah Republik Indonesia Nomor 12/Per/M.KUKM /IX/2015 tentang Pedoman Umum Akuntansi Koperasi Sektor Riil.

Peraturan Menteri Koperasi dan Usaha Kecil dan Menengah Republik Indonesia Nomor 13/Per/M.KUKM /IX/2015 tentang Pedoman Umum Akuntansi Koperasi Simpan Pinjam.
Sitepu, Sri Wangi, 2015, Analisis Prosedur Penyusunan Laporan Keuangan Koperasi Kencana Bhakti Nusantara Tebing Tinggi, Jurnal Ilmiah Accounting Changes, Vol. 3, hal 12-19.

Sunarto, 2006, Manajemen Koperasi, Penerbit Amus, Yogyakarta.

Undang Undang Republik Indonesia Nomor 25 Tahun 1992 tentang Perkoperasian.

Wahyuningsih, Tri, 2014, Uji Kepatuhan Penyusunan Laporan Keuangan Pada KPRI Warga Jaya Berdasarkan Standar Akuntansi Keuangan Entitas Tanpa Akuntabilitas Publik Pada Tahun Buku 2012, Jurnal Penelitian Ekonomi dan Bisnis, Semarang. 